DOI https://doi.org/10.30525/978-9934-588-92-1-81

\title{
ДЕЯКІ ПРОБЛЕМИ ПОВТОРНОСТІ КРИМІНАЛЬНИХ ПРОСТУПКІВ
}

\author{
Резніченко Г. С. \\ кандидат юридичних наук, доцент, \\ доцент кафедри кримінального права та кримінології \\ Одеського державного університету внутрішніх справ \\ м. Одеса, Україна
}

Законом України "Про внесення змін до деяких законодавчих актів України щодо спрощення досудового розслідування окремих категорій кримінальних правопорушень» від 22.11.2018 № 2617-VIII [1] до Кримінального кодексу України було введено поняття “кримінальне правопорушення", яке поділяється на кримінальний проступок та злочин.

Поняття кримінального проступку не $\epsilon$ новим для кримінального права України. Доцільність запровадження кримінального проступку у своїх працях досліджували В. I. Борисов, В. I. Тютюгін, Л. М. Демидова, В.А.Мисливий, Чернсй В. В., Є. С. Назимко, Н. А. Мирошниченко та інші, але повторність саме кримінальних проступків все ще потребує свого додаткового дослідження.

У зв'язку із введенням поняття кримінально проступку відбулися зміни у всіх інститутах кримінального права, у тому числі у інституті множини кримінальних правопорушень.

Метою цієї статті $\epsilon$ дослідження повторності кримінальних проступків, як одного із різновидів кримінальних правопорушень.

У ч. 1. ст. 32 КК України зазначено, що: «Повторністю кримінальних правопорушень визнається вчинення двох або більше правопорушень, передбачених тією самою статтею або частиною статті Особливої частини цього кодексу» [2]. У наведеному визначенні законодавець застосовує термін «Кримінальне правопорушення». Отже маємо розуміти, що поняття повторності стосується як кримінальних правопорушень, так i злочинів. Зазвичай виділяють такі види повторності: повторність тотожних кримінальних правопорушень, повторність однорідних кримінальних правопорушень, повторністьрецидив [3. с. 277-278]. Зазвичай ці види повторності стосувалися теорії злочину, але у зв'язку із введенням інституту кримінального проступку, доцільно дослідити яким чином правила визначення потворності можуть бути застосовані до кримінальних проступків. Що 
стосується злочинів, як різновиду кримінальних правопорушень, то теорія повторності залишилася майже без змін. Стосовно кримінальних проступків ситуація трохи інша. Якщо говорити про повторність тотожних кримінальних проступків, то за загальним правилом, яке зазначено у ч. 1. ст. 32 КК України [2], такою повторністю вважається вчинення особою повторно кримінального проступку, відповідальність за який передбачено тією самою статтею або частиною статті Особливої частини КК України, але якщо проаналізувати перелік кримінальних проступків, то доходимо висновку, що в диспозиції лише деяких кримінально-правових норм, які передбачають відповідальність за кримінальний проступок передбачено наявність такої кваліфікуючої ознаки як повторність, отже в усіх інших випадках, у разі повторного вчинення проступку, правозастосовним повинен додатково посилатися на п. 1 ст. 67 КК України [2], який викладений у такій редакції: «Вчинення злочину повторно та рецидив злочинів». Але законодавець у п. 1. ст. 67 КК використовую термін «Злочин» замість «Кримінальне правопорушення», яке охоплює не тільки поняття злочин, але й кримінальний проступок, отже маємо розуміти, що застосовувати посилання на п. 1 ст. 67 КК недоречно [2], оскільки цей пункт може бути застосований тільки при повторності злочинів. Проте виникає питання: «Як у формулі кваліфікації кримінального поступку позначати повторність?». Складається така ситуація, що правозастосовникам доведеться посилатися на ч. 1 ст. 32 КК [2], яка передбачає поняття та ознаки повторності кримінальних правопорушень, проте у цьому випадку повторність не можна визначати, як обставину, яка обтяжує кримінальну відповідальність особи, яка вчинила кримінальний проступок, і таким чином повторність не буде впливати на призначення покарання за повторність кримінального проступку.

Наступне, що привертає увагу це те, що аналіз переліку кримінальних проступків, дає можливість зробити висновок про те, що в одних випадках при повторному вчиненні кримінального проступку особа знову буде засуджена за тією ж статтею або частиною статті кримінально-правової норми Особливої частини КК України, і вчинене діяння буде залишатися кримінальним проступком, як наприклад при вчиненні діяння передбаченого ст.173 КК України «Грубе порушення угоди про працю» [2]. В інших випадках повторність передбачена як кваліфікуюча ознака діяння i повторне вчинення діяння буде передбачено вже як злочин, як наприклад, у статі 185 КК України «Крадіжка» [2]. Тобто стосовно повторності кримінальних проступків можна говорити про два іï види: фактична повторність і повторністьперехід, у випадку передбачення повторності як кваліфікуючої ознаки в 328 
кримінально-правовій нормі і кваліфікації повторно вчиненого кримінального проступку у якості злочину.

Отже поняття повторності кримінального проступку потребує свого додаткового дослідження в теорії Кримінального права.

\title{
Література:
}

1. Про внесення змін до деяких законодавчих актів України щодо спрощення досудового розслідування окремих категорій кримінальних правопорушень : Закон України від 22 листопада 2018 р. № 2617-VIII URL : https://zakon.rada.gov.ua/laws/show/720-20\#Text (дата звернення: 12.10.2020).

2. Кримінальний кодекс України : Закон України від 05.04.2001 № 2341-III URL : https://zakon.rada.gov.ua/laws/show/2341-14\#Text (дата звернення: 12.10.2020).

3. Кримінальне право України : загальна частина : Підручник / Ю.В. Баулін, Л.М. Кривоченко та ін.; За ред. проф. В.В. Сташиса, В.Я. Тація. -3 -є вид., перероб. і допов. - К.: Юрінком Інтер, 2007. $496 \mathrm{c}$.

DOI https://doi.org/10.30525/978-9934-588-92-1-82

\section{ДО ПИТАННЯ ЩОДО ВИЗНАЧЕННЯ ОТРИМУВАЧА}

\section{СЕКСУАЛЬНИХ ПОСЛУГ ПРИ ВПРОВАДЖЕННІ В УКРАЇНІ ШВЕДСЬКОЇ МОДЕЛІ ПРОТИДІЇ ПРОСТИТУЦІЇ}

\author{
Семчук Н. О. \\ кандидат юридичних наук, \\ дочент кафедри кримінального права \\ Національного авіаційного університету \\ Зайцева О. В. \\ аспірантка \\ Інституту держави і права імені В. М. Корецького \\ Національної академії наук України \\ м. Київ, Украӥна
}

Проблеми, пов'язані з торгівлею сексом, багато країн зараз вирішують за зразком, відомим у науці як «шведська модель» протидії проституції, яка криміналізує купівлю сексу, націлюючи правоохоронні 